\title{
John LoCKe E O ARgumento DA ECONOMIA PARA A TOLERÂNCIA
}

\author{
Antônio Carlos dos Santos ${ }^{l}$
}

\begin{abstract}
RESUMO: O objetivo deste texto é analisar o argumento da economia que justificaria a tolerância como um dos maiores fatores para o desenvolvimento dos povos, no século XVII, segundo a interpretação de Locke. Expressando de outro modo, este texto pretende responder a seguinte questão: qual o lugar da dimensão econômica na teoria lockiana sobre a tolerância?
\end{abstract}

PALAVRAS-CHAVE: Tolerância. Locke. Economia.

Se pudéssemos resumir numa sentença a diferença entre os antigos e os modernos, para lembrarmos o clássico texto de Benjamim Constant, diríamos que os antigos buscavam a "vida boa" e os modernos, a sobrevivência. Se os antigos tinham um ideal de "dever ser" com forte lastro ético, os modernos preocupam-se com a conservação da existência e, por isso, afastam a ética do comércio, como pensa Mandeville², dentre outros. Tomando como exemplo o pensamento de Hobbes, Léo Strauss demonstra que "[...] só o direito à vida é incondicional e absoluto". E conclui de maneira bastante enfática: “[...] todos os deveres derivam do direito fundamental e inalienável à vida”’ . A autoconservação tornou-se, assim, algo sagrado na modernidade, num mundo que racionaliza a religião, mas não se afasta de sua moralidade, uma vez que é essa moral que dará ao homem o seu norte, ao menos numa perspectiva lockiana.

\footnotetext{
${ }^{1}$ Professor de Ética e Filosofia Política da UFS. O presente texto faz parte de sua pesquisa, ainda em andamento, vinculada à Bolsa de Produtividade do CNPq. E-mail: acsantos12@uol.com.br

${ }^{2}$ Sobre essa questão, ver: SANTOS, A. C. Berkeley face a Mandeville: de La Fable des abeilles à La Lettre à Dion. Science et Esprit, 63/2, p. 163-177, 2011.
}

${ }^{3}$ STRAUSS, L. Droit naturel et histoire. Paris: Plon, 1954, p. 196. 
A preservação de si remete inevitavelmente à questáo da segurança e, por essa razão, da afirmação do indivíduo que ganha força no interior mesmo do estado de natureza: a subsistência passa a ser um direito natural e nada é pior do que a morte violenta, como se refere Hobbes. Se, no estado de natureza, sempre há a tentação de o homem exceder os seus limites e usurpar o que não lhe pertence, como vai defender Locke ${ }^{4}$, resta fundar uma instituição que possa fornecer as condiçóes materiais de exercício de sua livre existência e expressão, de tal modo que a vida não lhe seja ameaçada. Na esteira de Locke, resta ao Estado assegurar a vida, a liberdade e os bens dos indivíduos.

Ora, se um dos traços da vida moderna é a preservação da existência, paradoxalmente, o século XVII ainda sofria os resquícios das guerras de religiáo que assolavam a Europa no século anterior, por um lado, e das guerras políticas que dividiam povos, por outro ${ }^{5}$. Religião e política são, assim, faces distintas de uma moeda comum, que, sob um manto do sagrado, deixava rastro de violência. Todavia, para esta época, o que seria a sanção política sem a unçáo religiosa? $\mathrm{Ou}$, expressando de outro modo, o que seria a religiáo sem o aparato político e vice-versa? Por essa razão, os conflitos de religião, antes de tudo, são políticos. Mas como pôr fim a eles? Como romper com esse cerco? Grosso modo, há três tendências opostas, mas que têm relação e tentam responder essa questão. A primeira é unificando a religiấo e a política, resumida na antiga sentença francesa: "Um só Deus, uma só Igreja, um só Rei”. A segunda é submetendo a religião à política, o que poria a cristandade sob a proteção de um único reino. Mas qual o reinado que se aventuraria a impor-se como herdeiro único e absoluto de Deus? Como se vê, o enlace ou não da política com a religião se resume na unidade da fé num mesmo espaço político. O resultado prático dessa unidade foi o conflito religioso sangrento. A terceira e última é a tolerância, defendida por Locke, que é instituída pelo convencimento dos envolvidos de que é possível conviver com credos e religióes distintas num mesmo espaço, e que a paz depende tanto da religiáo quanto da política, para frear a violência. Limitando o poder político e controlando os excessos das religióes, Locke abre o caminho para a soberania do indivíduo até onde a lei permite.

\footnotetext{
${ }^{4}$ LOCKE, J. Two Treatises of Government (1690). Ed. P. Laslett. Cambridge: Cambridge University Press, 1988, $\$ 22$.

${ }^{5} \mathrm{O}$ século XVII fora o século das grandes mudanças, as quais tinham como foco a política e a religiâo. Sobre essa questão, ver: ASHCRAFT, R. La politique révolutionnaire et les "Deux traités du gouvernement" de John Locke. Paris: PUF, 1995, especialmente o segundo capítulo.
} 
No entanto, enquanto as lutas e os conflitos religiosos se acirravam, surge um outro argumento, ainda pouco explorado pelos pesquisadores vinculados à temática, que é o econômico. A base dessa ideia parece simples e óbvia, mas não era, no século XVII: a intolerância religiosa dificultava a produção agrícola, esterilizava o solo, travava o comércio entre os reinos, obstava o diálogo com diferentes povos. Sem a preservação da vida de cada indivíduo, não havia paz social e por isso as necessidades básicas ficavam ameaçadas. Ou seja, a tolerância poderia ajudar na circulação da riqueza e, por conseguinte, deveria ser inserida no debate sobre o campo da necessidade. Como afirma Rawls, o grande problema para o liberalismo político "[...] consiste em compreender como é possível existir, ao longo do tempo, uma sociedade estável e justa de cidadáos livres e iguais profundamente divididos por doutrinas religiosas, filosóficas e morais razoáveis, embora incompatíveis"6. Nesse sentido, estamos interessados nos efeitos materiais de um problema ao mesmo tempo político e religioso, e a questão que propomos é: qual o lugar da dimensão econômica, na teoria lockiana da tolerância?

Assim, o objetivo deste artigo é analisar o argumento da economia que justificaria a tolerância como um dos maiores fatores para o desenvolvimento dos povos no século XVII, em Locke. Para melhor desenvolvimento desse tema, o presente texto está dividido em duas partes: na primeira, serão analisados os principais argumentos da tolerância de Locke, concentrando a discussão na Carta sobre a tolerância; na segunda, serão discutidos alguns textos vinculados à economia, particularmente sua teoria sobre a propriedade ${ }^{7}$, dando prioridade à obra máxima, o Segundo tratado sobre o governo civil. Isso significa dizer que as ideias liberais políticas e religiosas de Locke vão exigir também uma abordagem econômica ${ }^{8}$, que tem como lócus central o tema da propriedade. Com isso, esperamos mostrar que esses textos fornecem elementos da filosofia para a compreensão do tema da economia em Locke

\footnotetext{
${ }^{6}$ RAWLS, J. O liberalismo político. Trad. Dinah de Abreu Azevedo. São Paulo: Ática, 2000, p. 25.

${ }^{7}$ A discussão econômica de Locke passa pelo tema da propriedade. O homem lockiano, ao menos a partir do Segundo tratado, é aquele que tem fome e que engendra um processo de apropriaçáo pelo trabalho que, como ponto de partida, é altamente privado e individual, posto que está vinculado à lei natural de conservação de si e do outro e que funda as relaçóes de obrigaçáo mútua, tornando possíveis os contratos, por exemplo. Sobre essa questâo, ver: TULLY, J. Locke, droit naturel et propriété. Paris: PUF, 1992.

${ }^{8}$ Segundo Raynaud, "[o] objeto da política liberal é de constituir um poder político que seja capaz de representar os interesses e resolver conflitos no sentido favorável ao bem público, respeitando ao mesmo tempo os direitos individuais e a lei natural, que é o seu fundamento". Philippe Raynaud. John Locke, fondateur du libéralisme? In: KÉVORKIAN, G. La pensée libérale: histoire et controverses. Paris: Ellipses, 2010, p. 31.
} 
e que ajudaram consideravelmente na consolidação da ideia de tolerância, no século XVIII.

\section{I}

Um dos principais argumentos para se justificar a intolerância religiosa é que as pessoas precisam encontrar a "Verdadeira religiáo", sobretudo segundo um de seus mais ardorosos defensores, Jonas Proast, e que para isso até a força bruta possibilitaria a volta do dissidente ao "caminho reto da religião". John Locke vai se opor a seu conterrâneo frontalmente, quando Proast escreveu $O f$ the Letter concerning Toleration, briefly considered and answered. Na resposta de Locke, duas premissas se entrelaçam e são fundamentais na sua crítica: a força é ineficaz no domínio da religiấo e somente uma separação clara e distinta das tarefas do Estado e da Igreja poderia pôr fim aos conflitos religiosos e políticos.

Convivendo num ambiente bastante propício à tolerância, a Holanda, durante os anos de 1680, Locke publica em latim, na cidade de Gouda, nove anos depois, a Epistola de tolerantia. Para ele, a perseguição não é justificada nem bíblica nem racionalmente. Num tom levemente irônico, afirma Locke: "Não me lembro de alguma vez ter lido no Novo Testamento que a verdadeira Igreja de Cristo deve perseguir os outros, ou atormentá-los, ou obrigá-los a abraçar a fé e os seus dogmas pela força, pela espada e pelas chamas" ${ }^{\prime \prime}$. Ora, se a religiáo serve para reger a vida das pessoas a partir das regras da virtude e da piedade, mesmo quando a razão já não é exercida, nada é mais desolador do que ser forçado a abraçar uma religiâo com a qual não se identifica. Se isso vale para a religião, vale também para a política.

Não se pode esquecer que, em 1662, Carlos II quis instituir uma tolerância, que logo depois se viu frustrada, por meio do Corporation Act. Por meio dele, eram excluídos

[...] das corporaçóes municipais os que se recusassem a receber os sacramentos segundo os ritos da igreja anglicana. O Act of Uniformity, de 1662, restabelecia o Common Prayer Book. Mas como os não-conformistas estavam excluídos das funçóes oficiais, suas religiốes e suas seitas eram admitidas a uma vida civil pela primeira vez pela lei. A perseguição estava acompanhada por uma espécie de reconhecimento. ${ }^{10}$.

${ }^{9}$ LOCKE, J. Four letters concerning toleration: the works of John Locke, vol. VI. London: Tegg, 1823. Reproduzida em fac-simile por Scientia Verlag, Aalen, 1963, p. 15.

${ }^{10}$ POLIN, R. Introduction. In: John Locke: Lettre sur la tolérance. Paris: Quadrige/PUF, 2006, p. LKVI. 
Isso significa dizer que, como se já não bastasse a intolerância religiosa per si, o Estado legitimava a perseguição sobre os dissidentes, sob o comando dos bispos, apontando para uma espécie de intolerância institucionalizada, contrária ao próprio espírito do estado, que é promover a paz.

Richard Hooker, ao defender a obrigação do Estado em proteger e promover a religiáo, tendo em vista sua estreita ligaçáo, afirma: "Nenhuma outra prova se faz necessária para mostrar que o homem deva primeiro almejar o reino de Deus: portanto, de tudo aquilo oferecido pelas comunidades, o espiritual deve prevalecer sobre as coisas temporais. E de todas as coisas espirituais, a religião é a principal" ${ }^{\prime 1}$. Se o bem máximo humano é a sua alma e se a sua salvação passa necessariamente pela religião, nada mais justo do que o Estado promover esse bem-estar. Em vista de tal argumento, a Igreja anglicana exige que o Estado inglês a sustente e, o que é mais delicado, reprima as religióes contrárias a ela. Unidos politicamente a uma única fé, Igreja e Estado conduzem os não-conformistas rumo à salvação. Vê-se, aqui, que a matriz teológica fincou raízes profundas na política moderna. Segundo Christopher Hill, a Igreja anglicana era o veículo de comunicação por excelência do Estado e sobrevivia em larga medida graças às benesses dele: "'A religião é o único alicerce firme para todo o poder', dissera Carlos I. 'A Igreja e o Estado apoiam-se e assistem-se mutuamente', escreveu o bispo Goodman. 'O Estado paga o clero, e assim este depende do Estado', afirmou, com mais crueza, Hugh Peter" ${ }^{\prime 2}$. Eis o resumo das estreitas vinculaçôes entre política e religiấo, na Inglaterra do século XVII, que poucos ousariam garantir onde uma começava ou a outra terminava.

Ora, na Epistola, um dos argumentos mais notáveis que afronta diretamente tanto a Igreja anglicana quanto o Estado inglês é exatamente o político: é preciso separar as tarefas e competências de cada instância, limitando-as em espaços precisos e, com isso, promover a liberdade religiosa. Por essa razão, afirma Locke:

[...] se a lei da tolerância não estabelecesse que todas as igrejas fossem obrigadas a ensinar e a pôr como fundamento da sua própria liberdade que os outros, ainda que divirjam de si em matéria de religião, devem tolerarse, e que ninguém deveria ser constrangido pela lei ou pela força no campo religioso; estabelecido isto, eliminar-se-ia todo o pretexto de querelas e de tumultos em nome da consciência. E, sendo uma vez removida estas causas de descontentamento e animosidade, nada restaria nestas assembleias que

${ }^{11}$ HOOKER, R. Of Laws of Ecclesiastical Polity. Great Britain: Cambridge University Press, 1997, p. 132.

${ }^{12}$ HILL, C. O mundo de ponta-cabeça. São Paulo: Companhia das Letras, 1987, p. 110. 
não fosse mais pacífico, e menos apto a produzir perturbação no Estado, que em quaisquer outras reuniōes. ${ }^{13}$

Ou seja, à religiáo cabe o trabalho da consciência, ao Estado, a busca pela paz pública. Cada instituição tem, separadamente, as suas funçóes e competências, de tal modo que uma não deve intervir no campo da outra.

Locke também ataca a velha doutrina do único corpo do rei, em que se filiaria a unidade da Igreja e do Estado. ${ }^{14}$ Sendo a sociedade a uniáo de homens livres que decidem sobre si, só deve fazer parte dela quem aceita livremente as suas regras. Por essa razão, a religião é uma "persuasão interna da mente", não uma questão de força ou de lei civil, de forma que o Estado vai proteger essa mesma sociedade e, sobretudo, a propriedade de cada pessoa contra sua violação por parte de terceiros. Por essa razão, Locke argumenta, na Carta sobre a tolerância de 1689, que "[...] é o dever do magistrado civil determinar imparcialmente leis uniformes, assegurar para o povo em geral, e para cada um dos seus súditos em particular, a posse justa dessas coisas que pertencem a esta vida". ${ }^{15}$

Nesse sentido, o Estado não tem nada a ver com salvação das almas, limitando-se às questóes terrenas, como a econômica, por exemplo. Pondo o Estado no regime da necessidade física, e não do espiritual, Locke vai defender a hipótese de que pode haver prosperidade do Estado com o fim dos conflitos religiosos e a (consequente) sociabilidade política. Se levarmos as palavras de Locke ao extremo, podemos interpretar que a funçáo do Estado é meramente econômica, haja vista que, se ele protege o cidadão, estaria protegendo, por conseguinte, uma propriedade. Aqui, tolerância religiosa e política se unem em virtude de outro fator, o econômico: a prosperidade, a circulaçáo e a distribuição das riquezas são compatíveis com a liberdade de religião e, por isso, com a própria ideia de tolerância.

\footnotetext{
${ }^{13}$ LOCKE, J. Four letters concerning toleration: the works of John Locke, vol. VI. London: Tegg, 1823. Reproduzida em fac-simile por Scientia Verlag, Aalen, 1963, p. 48.

${ }^{14}$ Sobre a unidade do corpo místico do rei, ver o clássico KANTOROWICZ, E. Os dois corpos do rei. São Paulo: Companhia das Letras, 1998.

${ }^{15}$ LOCKE, J. Four letters concerning toleration: the works of John Locke, vol. VI. London: Tegg, 1823. Reproduzida em fac-simile por Scientia Verlag, Aalen, 1963, p. 10.
} 


\section{II}

Como se sabe, no século XVII não havia o que hoje denominamos economia. Isso, no entanto, nunca impediu que muitos pensadores refletissem sobre práticas econômicas, levando-os, inclusive, a elaborarem teorias ${ }^{16}$ que permitiram a Adam Smith e Ricardo comporem a teoria econômica, ainda no século XVIII. Nessa passagem de um século para outro, em que esse saber se estrutura e ganha autonomia pelo caráter científico, não poderiam estar desvinculadas de duas forças que andavam juntas no mesmo solo: a política e a religião, conforme anunciamos na primeira parte deste texto. Afinal, como entender o conceito de propriedade em Locke, sem compreender a ética calvinista? Como descolar sua teoria da resistência política da antiga ordem religiosa? Como dissociar a revoluçáo constitucional inglesa de 1688 da religião? Segundo Paul Hazard, "[...] essa revolução não foi somente política, mas religiosa; o triunfo de Guilherme de Orange não foi somente aquele do Parlamento, mas ainda aquele da Reforma; não se exaltou somente, em sua pessoa, o defensor dos direitos dos povos, mas o salvador da religiáo, o herói do Protestantismo"17. Isso significa dizer que a novidade da revolução política inglesa exigiu também uma nova perspectiva religiosa e econômica. A recusa de Locke em aceitar a antiga ordem religiosa é a mesma que o impede de aceitar a opressáo política e, dessa maneira, os calvinistas representam a liberdade de consciência religiosa e política, bem como um campo de atuação vinculado às necessidades da sobrevivência básica do homem. Em Locke, esse campo engloba uma dimensão teórica e outra prática: a primeira compreende um corpo de leis econômicas; a segunda, a mobilização de experiências vinculadas ao mundo do vivido, nos limites das leis de valor. ${ }^{18}$

Em função da nova ordem política, a Revolução Gloriosa, Locke vai escrever vários textos sobre economia ${ }^{19}$, com vistas a fornecer um lastro

\footnotetext{
${ }^{16}$ Dizer que existiria no século XVII uma ciência econômica seria um anacronismo. Porém, existiam teorias econômicas, de que Locke é o grande exemplo. Ele desenvolveu uma teoria econômica cujo aspecto principal era o valor. Sobre essa questão, ver: LETWIN, W. The origins os scientific economics. London: Mathuen, 1963.

${ }^{17}$ HAZARD, P. La Crise de la conscience européenne. Paris: Gallimard, 1961, p. 115.

${ }^{18}$ Segundo Karen I. Vaughn, Locke foi um dos maiores economistas e precursores da teoria do valor de Marx. Ver: John Locke and the labor theory of value. Journal of Libertarian Studies Vol. 2. No. 4, p. 311-326, 1978.

19 Locke economista é apresentado num estudo, seguido da tradução de um de seus textos mais importantes vinculados à economia. Cf. PAIXÃO, W. R. P. In: LOCKE, J. Consideraçôes sobre as
} 
filosófico à nova teoria que iria se ocupar de suprir as necessidades básicas de um novo tempo, a qual ficaria conhecida muito tempo depois como "liberalismo". Com isso, não queremos dizer que a obra de Locke, particularmente os "Dois tratados", tenha relação necessária com a revolução constitucionalista inglesa. As últimas pesquisas de Laslett já demonstraram largamente isso ${ }^{20}$. O que se deseja apontar aqui é que, nessa obra máxima de Locke, se vê de forma clara a sua preocupação em fornecer um lastro filosófico, quer à nova ordem políticoreligiosa, quer como um fundamento econômico, embora, nessa questáo, dê forte importância à perspectiva moral.

Antes da publicação do "Segundo Tratado", em 1674, Locke lançou um pequeno texto intitulado "Comércio". Podemos entender esse fato segundo o contexto da época em que, logo após a Revolução Gloriosa, Locke foi designado membro da Câmara do Comércio e suas funções incluíam a formulação e administração da política do governo. ${ }^{21}$ Nesse escrito, ele começa especificando a finalidade do comércio: as riquezas e o poder que geram uns aos outros. $\mathrm{Ou}$ seja, a finalidade do comércio é provocar a circulação da riqueza. Todavia, o que seria a riqueza? O próprio Locke define: "[...] consiste na abundância de bens móveis, que rendem um preço a um estrangeiro e não são próprios do consumo interno, mas especialmente na abundância de ouro e prata". ${ }^{22}$

Esse pequeno texto de Locke expressa bem o contexto do mercantilismo da época: uma nação é mais poderosa, à medida que concentra ouro e prata. E, mais, se até no mundo medieval o comércio se limitava às feiras e às transações internas, numa visão bastante modesta, a partir do século XVI, grosso modo, o comércio voltava-se para o exterior, buscando o acúmulo de capitais em função da prosperidade do Estado, mesmo que para isso fossem necessárias a exploração de outras terras e a submissão de outros povos. $\mathrm{O}$ descobrimento de novas terras, sobretudo a partir de Colombo, deu-se neste espírito: o de

consequências da redução do juro. São Paulo: Humanitas, 2005.

${ }^{20}$ LOCKE, J. Two Treatises of Government (1690). Ed. P. Laslett. Cambridge: Cambridge University Press, 1988.

${ }^{21}$ Paixão assim resume esse período: "Se, no período anterior à Revolução Gloriosa, Locke assessora o ousado e hábil Shaftesbury como uma espécie de 'co-ideólogo' da oposição, e só secundariamente como administrador público, no período posterior, ele se ligará pessoalmente a Somers como seu conselheiro, mas o servirá no governo principalmente como formulador e administrador de políticas econômicas, enfim, um commissioner". PAIXÃO, W. R. P. In: LOCKE, J. Consideraçôes sobre as consequências da redução do juro. São Paulo: Humanitas, 2005, p. 31.

${ }^{22}$ LOCKE, J. Political essays. Ed. Goldie, Mark. Cambridge: Cambridge University Press, 1997, p. 280. 
busca e exploração das riquezas e acúmulo de bens ${ }^{23}$. Conhecedor dessa prática, Locke defende dois tipos de comércio: o interno, manufatureiro, que seria a mercadoria preparada para a troca por meio do trabalho, e o externo, que necessitaria do transporte, da navegação, conduzindo assim a mercadoria para bem longe de onde ela foi produzida. Seja num, seja noutro, a circulação da riqueza passa a ser fundamental. Registra Locke: "O poder consiste em inúmeros homens e na capacidade de os manter. O comércio conduz a essas duas coisas pelo aumento de vosso capital e de vossa gente, e estes reciprocamente" 24 .

Ainda nesse texto, dois aspectos são notáveis. O primeiro é que Locke faz uma divisão entre as pessoas que impulsionam o comércio, tanto por meio do trabalho, quanto da própria movimentação da agricultura, das minas e da navegação, dentre outros; e o segundo é que ele elenca os fatores que estimulam ou obstam o comércio. No que concerne aos primeiros, Locke destaca a liberdade de religiaáo, de comércio, de registro ou convicção da propriedade, baixos impostos, dentre outros. No que tange ao segundo aspecto, elenca a complexidade da legislação, o poder arbitrário, os vícios. Enfim, numa sentença, Locke deixa claro que a tolerância favorece o desenvolvimento do comércio e a falta dela dificulta imensamente a produção de bens, a circulação da riqueza, que depende dela para sobreviver. Por isso, enfatiza Locke que "[...] resta ainda mostrar a influência que a tolerância pode ter sobre o número e a indústria de nosso povo, do qual dependem o poder e as riquezas do reino". 25 Ou seja, o que Locke defende é que as guerras de religião, que são também políticas, conduzem à instabilidade econômica, as quais dificultam a livre circulação de riqueza e trazem graves danos ao governo. ${ }^{26}$

Mas, se o comércio aparece em Locke como fator de fundamental importância para a prosperidade dos povos e a tolerância passa a ser uma forte aliada, nessa relaçáo, nada tem maior peso do que a propriedade privada. Como se sabe, desde o final do século XVI inglês, a partir do aprimoramento da manufatura, os tecidos passaram a substituir a lã na condição de primeiro artigo de exportação. O comércio em alta também atraía o avanço das

\footnotetext{
${ }^{23}$ ETNER, F. Mercantilisme. Encyclopédie thématique Universalis. Paris: s/ed, 2005.

${ }^{24}$ LOCKE, J. Political essays. Ed. Goldie, Mark. Cambridge: Cambridge University Press, 1997, p. 280.

${ }^{25}$ LOCKE, J. Political essays. Ed. Goldie, Mark. Cambridge: Cambridge University Press, 1997, p. 260.

${ }^{26}$ Letwin registra que Locke participou ativamente dos debates em torno das questôes econômicas inglesas do período, graças às necessidades ou influência do Lord Ashley, que, além de poderoso politicamente, tinha particular interesse nos assuntos da economia. WILLIAM, L. The origins of scientific economics. London: Methuen \& Coltd, 1963, p. 167.
} 
organizaçóes financeiras, das manufaturas mais avançadas, minando cada vez mais a agricultura familiar, que remontava às aldeias medievais. Nesse sentido, o conceito de propriedade era entendido, sobretudo, como acúmulo de terras. Ora, desde o confisco da propriedade dos monastérios, entre 1536 e 1540, e com o agravamento dessa situação com Henrique VIII e, mais tarde, com Cromwell, a terra passou a ser um problema grave, na Inglaterra. ${ }^{27}$ Contudo, se considerarmos a terra como único elemento da propriedade, não se estaria aí reduzindo demasiadamente seu conceito? Para náo cair em reducionismo, Locke vai, ao contrário, ampliá-lo sob dois aspectos inteiramente novos: a prosperidade e a segurança.

É sempre bom relembrar que, desde a Idade Média, a Igreja critica o lucro e a ganância ou toda forma ilimitada de exploraçáo ou de apropriação. Ora, na passagem do século XVI para o XVII, começa um movimento de crítica dessa maneira de lidar com o comércio, de tal forma que haverá uma considerável mudança na Inglaterra. Segundo Max Weber, no seu clássico "A ética protestante e o espírito do capitalismo", essa mudança se deu graças à religião reformada, precisamente por Calvino, na versão puritana. Continuam os lucros, mas, doravante, náo ilimitados, pois terão um fim em si mesmo. Entretanto, como explicar o surgimento de ideias individualistas da propriedade para as quais Locke deu uma precisão filosófica? Para se entender essa questão, é necessário compreender o conceito de propriedade em Locke, porque, a partir da propriedade é que teremos a possibilidade de pensar em prosperidade e segurança.

Antes, porém, convém recordar duas tendências políticas que rivalizavam na Inglaterra, em pleno século XVII, as quais tinham interpretaçóes distintas sobre a propriedade: os "Levellers" e os "Diggers". Os primeiros eram considerados republicanos e democráticos, e por isso eram contra os privilégios políticos da nobreza e as vantagens comerciais advindas do monopólio, mas sem ataques à propriedade. Seu programa de reforma fazia a defesa da população pobre da cidade e do campo, e exigia a completa igualdade dos homens perante a lei, a abolição dos monopólios comerciais, dos dízimos, uma profunda reforma judiciária e plena liberdade religiosa. ${ }^{28}$ Propunham a igualdade à lei e aos direitos políticos, de modo particular, aos pequenos

\footnotetext{
${ }^{27}$ HILL, C. O eleito de Deus: Oliver Cromwell e a revolução inglesa. São Paulo: Companhia das Letras, 1988, p. 181 ss.

${ }^{28}$ Sobre essa questão, sobretudo na crítica à visão democrática dos "levellers", ver: BARROS, A. R. G. Levellers e os direitos e liberdades constitucionais. Cadernos de Ética e Filosofia Política, n. 17, 2010.
} 
proprietários. Assim, afirma Richard Overton, um de seus maiores defensores do período: "Para cada indivíduo na natureza, é dado uma propriedade individual por natureza, não para ser invadida ou usurpada por ninguém" ${ }^{29}$. Já os "Diggers" fazem duras críticas à propriedade. Formados por camponeses que defendiam uma sociedade corporativa, entendiam que a Revolução Inglesa era o momento oportuno para fazer mudanças sociais e políticas profundas, como a da distribuição das terras. Distribuindo-as, distribuir-se-iam as riquezas e, com isso, se faria jus à revolução.

A importância dos "Diggers" repousa quase inteiramente no domínio da teoria. Em seus esforços para eliminar as desigualdades sociais e econômicas, particularmente na posse da terra, eles salientam a inadequação da democracia política sem democracia econômica. A Inglaterra nunca seria uma sociedade livre, eles afirmavam, até que todos os pobres homens do povo tivessem acesso à terra. A aboliçấo da propriedade privada da terra melhoraria as relaçôes entre indivíduos e entre naçôes e superaria as dificuldades iniciais para reformas sociais mais amplas. ${ }^{30}$

Apesar de pouca influência nas ações decisórias do século XVII, os "Diggers" são um caso à parte, pois defendiam a distribuição da terra de forma radical. ${ }^{31}$ Como se vê, tanto os "Leverllers" quanto os "Diggers" se preocupam com a propriedade, mas têm visóes distintas de como atacá-la. Ora, como Locke se posiciona?

O conceito de propriedade em Locke é central na sua teoria econômica do Segundo tratado. Se, para a maioria dos pensadores do século XVII, a propriedade surge a partir da institucionalização do Estado, para Locke este surge apenas para garanti-la e protegê-la, pois ela já existia no estado de natureza. O problema maior, no entanto, é saber como se passa de uma suposta propriedade comum, dada por Deus, para a privada.

Aceitando a ideia de um comunismo primitivo, Locke defende que o surgimento da propriedade está vinculado à própria natureza humana e ao trabalho humano, porque "[...] todo homem tem uma propriedade em sua própria pessoa: a isto ninguém, a não ser a própria pessoa, tem qualquer direito. Podemos dizer que o labor de seu corpo e o trabalho de suas mãos são

\footnotetext{
29 "Levellers". In: Encyclopaedia of Social Sciences.

30 "Diggers". In: Encyclopaedia of Social Sciences.

${ }^{31}$ FADUL, A. Categorias politicas e econômicas no Segundo tratado sobre o governo civil de Locke. USP, 1972.
} 
naturalmente seus". ${ }^{32}$ Esse comunismo primitivo só estará descartado após o advento do dinheiro; antes disso temos duas categorias éticas que asseguravam: 1) o uso, 2) o desperdício. Ao retirar da natureza o bem comum e introduzir a categoria "trabalho" como forma de aquisição da propriedade privada, Locke privilegia o indivíduo enquanto força detentora da propriedade. Mas essa ideia não é suficiente para afirmar que Locke defenda exclusivamente os interesses individuais. Cada homem possui uma propriedade em si mesmo, dentro do estado de natureza, o que não é a mesma coisa no estado civil. "O trabalho do indivíduo, portanto, conquanto um estádio necessário, é somente o estágio final no processo de criação de propriedade", como afirma Gough ${ }^{33}$. Isso porque, quando o indivíduo passa do estado natural para o contratual, concorda que aquilo que cada um havia tomado para si o seu próprio uso deve ser reconhecido como seu e por isso protegido por lei. A propriedade, assim, não nasce com a institucionalização do Estado, mas é assegurada com o seu nascimento.

Se a propriedade já existe no estado natural, há sempre o perigo de alguém "abarcar tanto quanto queira" e, com isso, ameaçar o direito comum de todos à autopreservação. Se Deus deu ao homem um mundo cheio de riquezas, Ele, por outro lado, não lhe deu para que se estragasse ou que seus frutos fossem destruídos. Por isso, o excedente pertence a terceiros e não a si. Vê-se aqui o lado de Locke mais comunitarista, preocupado com o bem comum. Contudo, todo esse empenho em demonstrar a preocupação comum dura pouco, pois a entrada do dinheiro acarreta sérios problemas, porque, no estado de natureza, com a introdução do dinheiro, que possibilita a troca e o comércio, torna-se possível também a apropriação de tudo em larga escala. Se Locke póe limite sobre a propriedade na lei de natureza, ele o retira quando o dinheiro é introduzido. Eis a virtude e os limites de sua teoria, nessa questão.

Tendo o mérito de opor-se às teorias medievais sobre a propriedade, por um lado, e à tradiçáo do direito natural, que considerava a propriedade enquanto fruto do contrato, por outro, Locke amplia tal conceito, incluindo aí "a vida, a liberdade e os bens de raiz", isto é, os direitos naturais de um ser humano. Nas próprias palavras de Locke: "Os homens passam a viver em sociedade para melhor preservarem a si, sua liberdade e sua propriedade". ${ }^{34}$

32 LOCKE, J. Two Treatises of Government (1690). Ed. P. Laslett. Cambridge: Cambridge University Press, 1988, \$140.

${ }^{33}$ GOUGH, J. W. A teoria de Locke sobre a propriedade. In: QUIRINO, C. G.; SADEK, M. O pensamento político clássico. São Paulo: Martins Fontes, 2003, p. 202.

${ }^{34}$ LOCKE, J. Two Treatises of Government (1690). Ed. P. Laslett. Cambridge: Cambridge University Press, 1988, \$131. 
Ou seja, com a propriedade, o homem pode prosperar por meio do trabalho e do empreendimento e este, por sua vez, vai ser assegurado e protegido pelo Estado. Aqui está, na verdade, a razão de ser do Estado. Isso significa dizer que desde o estado natural o homem tem um direito natural à sobrevivência, que passa pela propriedade individual e é assegurada na passagem para o Estado constitucional, quer dizer, a sociedade política. Como afirma Ashcraft, "Locke certamente crê que o direito natural de subsistência continua, no tempo, como uma exigência moral obrigatória no estado mais avançado ou civilizado da sociedade". 35

Assim, os homens se movem de uma existência de trabalho ou consumo familiar a uma sociedade de produçáo para a troca e de intercâmbio ${ }^{36}$, graças à moeda e ao trabalho braçal, necessitando, para isso, de uma legislação para regular seus direitos e garantir sua segurança. Essa organização da vida social só pode beneficiar a todos, porque a riqueza circula, mesmo entre os indivíduos de menor posse, dando-lhes não só bens materiais, mas sobretudo a obrigação moral de que toda a humanidade será preservada.

O conceito de propriedade em Locke náo diz respeito apenas a uma descrição dos bens numa economia de troca nem tampouco à organização do corpo constitucional. Ele está vinculado à ideia de que, pela propriedade, estáo asseguradas a prosperidade e a continuidade da vida; por essa razáo, a vida política organizada traz segurança. O poder legislativo vai, enfim, corrigir injustiças, resolver conflitos, contornar impasses econômicos, sociais, políticos e religiosos. E se o Estado não for capaz de desempenhar as funçóes para as quais fora designado? Locke é claro: o povo tem o poder de resistir e, por isso, pode se rebelar contra o poder instituído.

Ora, é nesse contexto que o problema da tolerância em Locke se mistura à questão política e econômica. Se a propriedade envolve os bens, a liberdade e a vida dos indivíduos, a ameaça da vida, por meio dos conflitos religiosos, precisamente pela oposição à diversidade de religião, inviabiliza a convivência social, prejudica as relaçóes comerciais e põe em risco o pacto constitucional.

\footnotetext{
${ }^{35}$ ASHCRAFT, R. A filosofia política. In: Locke. Aparecida: Ideias e Letras, 2011, p. 301.

${ }^{36}$ A propósito dessa questão, Fernand Braudel afirma: "Entre a 'vida material' (no sentido de economia muito elementar) e vida econômica, a superfície de contato, que não é contínua, materializa-se em milhares de pontos modestos: feiras, bancos, lojas... Esses pontos são todos eles rupturas: de um lado, a vida econômica com suas trocas, suas moedas, seus pontos nodais e seus meios superiores, praças comerciais, bolsas ou grandes feiras; do outro, a 'a vida material', a náo-economia, sob o signo da auto-suficiência. A economia começa no limiar do valor de troca”. BRAUDEL, F. Civilização material, economia e capitalismo: séculos XV-XVIII. São Paulo: Martins Fontes, 2009, p. 7.
} 
Por conseguinte, a tolerância civil é parte do "pacote" de termos assinados no momento da entrada do indivíduo no estado civil, porque ela é condição de subsistência de seus consignatários. Se o Estado não garante esse minimum minimorum, ele não tem razáo de ser e por isso a soberania volta para os braços do povo. É isso que constitui uma de suas maiores inovaçóes políticas no século XVII inglês: mesmo na condição de indivíduos, os homens podem, pela racionalidade e independência, orientar suas açóes tendo em vista o bem comum. A tolerância é um bom exemplo.

Enfim, a dimensão econômica da teoria lockiana da tolerância está vinculada à satisfação de suas necessidades básicas como o direito à vida e à sobrevivência. Cabe ao Estado possibilitar ao indivíduo o direito à liberdade de religião, ao livre comércio, à livre circulação das riquezas, ao poder de decisão do indivíduo, à própria tolerância civil. Ao defender essa posição em suas obras, Locke se mostra ao mesmo tempo um republicano e um liberal. Republicano, uma vez que privilegiou a igualdade dos cidadãos diante da lei para promover a liberdade como ausência de dominaçáo. Liberal, porque defendeu a limitação do poder político, visando a reduzir os obstáculos à expansão do poder dos indivíduos em função de seus objetivos privados, inclusive, econômicos. Se, no primeiro caso, vemos o poder das instituiçóes, no segundo, vemos a força dos indivíduos. Nos dois casos, a lei se torna a expressão máxima de obediência em um mundo civilizado. Assim como devemos obedecer às regras mínimas da lei de sobrevivência, precisamos fazer o mesmo com os assuntos religiosos. Afinal, a liberdade religiosa, fundamento primeiro da tolerância lockiana, só pode ser exercida num quadro de outras liberdades, como a econômica.

SANTOS, Antônio Carlos dos. John Locke and argument from economy for tolerance. Trans/Form/Ação, Marília, v. 36, n. 1, p. 9-24, Jan./Abril, 2013.

\begin{abstract}
The objective of this text is to analyze the economic argument that justifies tolerance as a major contributor to the development of peoples in the seventeenth century, according to the interpretation of Locke. Put another way, this paper aims to answer the following question: What is the place of the economic dimension in the Lockean theory of tolerance?
\end{abstract}

KEYWORDS: Tolerance. Locke. Economy. 


\section{REFERÊNCIAS}

ASHCRAFT, R. A filosofia política. In: Locke. Aparecida: Ideias e Letras, 2011.

ASHCRAFT, R. La politique révolutionnaire et les "Deux traités du gouvernement" de John Locke. Paris: PUF, 1995.

BARROS, A. R. G. Levellers e os direitos e liberdades constitucionais. Cadernos de Ética e Filosofia Politica, n. 17, São Paulo, 07-20, 2010.

BRAUDEL, F. Civilizaçaao material, economia e capitalismo: séculos XV-XVIII. São Paulo: Martins Fontes, 2009.

DIGGERS. In: ENCYCLOPAEDIA of Social Sciences. New York: The Free Press, 1972.

ETNER, F. Mercantilisme. In: Encyclopédie thématique Universalis. Paris: s/ed., 2005.

FADUL, A. Categorias politicas e econômicas no Segundo tratado sobre o governo civil de Locke. São Paulo: Editora da USP, 1972.

GOUGH, J. W. A teoria de Locke sobre a propriedade. In: QUIRINO, C. G.; SADEK, M. O pensamento político clássico. São Paulo: Martins Fontes, 2003.

HAZARD, P. La Crise de la conscience européenne. Paris: Gallimard, 1961.

HILL, C. O mundo de ponta-cabeça. Sáo Paulo: Companhia das Letras, 1987.

. O eleito de Deus: Oliver Cromwell e a revolução inglesa. Sáo Paulo: Companhia das Letras, 1988.

HOOKER, R. Of Laws of Ecclesiastical Polity. Great Britain: Cambridge University Press, 1997.

KANTOROWICZ, E. Os dois corpos do rei. São Paulo: Companhia das Letras, 1998.

LETWIN, W. The Origins of Scientific Economics. London: Mathuen, 1963.

LEVELLERS. In: ENCYCLOPAEDIA of Social Sciences. New York: The Free Press, 1972.

LOCKE, J. Two Treatises of Government (1690). Ed. P. Laslett. Cambridge: Cambridge University Press, 1988.

LOCKE, J. Political essays. Ed. by Goldie, Mark. Cambridge: Cambridge University Press, 1997.

LOCKE, J. Four letters concerning toleration: the works of John Locke, vol. VI. London: Tegg, 1823. Reproduzida em fac-simile por Scientia Verlag, Aalen, 1963.

PAIXÃO, W. R. P. In: LOCKE, J. Considerações sobre as consequências da redução do juro. São Paulo: Humanitas, 2005.

POLIN, R. Introduction. In: John Locke: Lettre sur la tolérance. Paris: Quadrige/PUF, 2006. RAWLS, J. O liberalismo político. Trad. Dinah de Abreu Azevedo. São Paulo: Ática, 2000. 
RAYNAUD, P. John Locke, fondateur du libéralisme? In: KÉVORKIAN, G. La pensée libérale: histoire et controverses. Paris: Ellipses, 2010.

SANTOS, A. C. Berkeley face a Mandeville: de La Fable des abeilles à La Lettre à Dion. Science et Esprit, 63/2, p. 163-177, 2011.

STRAUSS, L. Droit naturel et histoire. Paris: Plon, 1954.

TULLY, J. Locke, droit naturel et propriété. Paris: PUF, 1992.

VAUGHN, K. I. John Locke and the labor theory of value. Journal of Libertarian Studies, Vol. 2. No. 4, p. 311-326, 1978.

WEBER, M. A ética protestante e o espírito do capitalismo. 5. ed. São Paulo: Pioneira, 1987. WILLIAM, L. The origins of scientific economics. London: Methuen \& Coltd, 1963. 